\title{
PERKAWINAN SIRRI DALAM PERSPEKTIF HUKUM DI INDONESIA
}

\author{
Supriyadi \\ Email:supriyadi_rama@yahoo.co.id
}

\begin{abstract}
The phenomenon of sirri marriage occurs in many communities, as if the community is permissive to the marriage. They believe that the marriage of sirri is legal according to local law and does not contradict the ethical value of society. This certainly requires a deep legal examination so as not to become a wrong view by the community. Therefore, in this paper, a juridical normative approach is used to analyze sirri farming. The results show that the marriage of Sirri is an illegitimate marriage in the perspective of Marriage Law No. 1 of 1974. Marriage sirri does not have an authentic deed, so someone who makes a marriage sirri will find it difficult to prove the occurrence of marriage.
\end{abstract}

Key words: marriage, sirri, law

\section{A. Pendahuluan}

Perkawinan merupakan masalah penting bagi kelangsungan hidup manusia, dengan melalui perkawinan manusia akan berharap memperoleh keturunan untuk meneruskan silsilah kehidupannya. Dalam perkawinan tidak hanya menyangkut mempelai pria atau wanita saja, tetapi juga tetapi juga orang tua kedua belah pihak dan keluarga-keluarga mereka masing-masing. Bahkan dalam hukum adat suatu perkawinan diharapkan menjadi keluarga yang bahagia dan sejahtera serta hidup rukun sampai kakenkaken ninen ninen ( istilah jawa yang artinya sang suami menjadi kaki-kaki dan sang istri menjadi nini-nini yang bercucu cicit). Begitu penting masalah perkawinan sehingga pemerintah merasa perlu mempunyai sebuah undangundang yang mengatur tentang perkawinan secara nasional, yang berlaku bagi semua golongan dalam masyarakat Indonesia, yaitu suatu unifikasi hukum perkawinan. 
Prinsip dasar dalam perkawinan adalah menghalalkan hubungan antara seorang laki- laki dengan seorang perempuan yang oleh masyarakat disebut sebagai hubungan suami istri. Adanya hubungan tersebut diharapkan timbul hak dan kewajinan antara suami istri yang dibenarkan menurut tuntutan agama. Dalam kaca mata agama jelas bahwa perkawinan merupakan akad yang suci antara seorang laki laki dengan seorang perempuan. Tujuannya adalah untuk membentuk keluarga yang sakinah, mawadah dan rohmah. Akad dalam perkawinan tentu berpedoman syarat dan rukunnya perkawinan. Tidak boleh perkawinan itu bertentangan dengan syarat dan rukun yang telah ditetapkan. Perkawinan yang melanggara syarat dan rukum perkawinan maka akan dianggap tidak sah dan sebaliknya perkawinan yang telah sesuai dengan syarat dan rukum perkawinan maka perkawinan dianggap telah sah menurut hukum agama.

Lahirnya Undang-Undang Perkawinan tepatnya tanggal 2 Januari 1974 yaitu Undang-Undang Nomor 1 Tahun 1974 merupakan hasil karya yang membanggakan bagi bangsa Indonesia. Undang-Undang ini merupakan ketentuan hukum yang maju sesuai dengan suasana kemerdekan bangsa Indonesia berdasarkan falsafal pancasila dan Undang-Undang Dasar 1945. Dan aturan pelaksanannya menggunakan Peraturan Pemerintah Nomor 9 Tahun 1975 yang berlaku efektif tanggal 1 Oktober 1975, selanjutnya disingkat UU 1/1974 dan PP 9/1975.

Meskipun kita telah mempunyai Undang-Undang tentang perkawinan yang bersifat nasional, tetapi kita harus menyadari bahwa didalam pelaksanaannya tanpa dukungan penuh dari masyarakat akan timbul ketimpanganketimpangan, sehingga pasal-pasal yang terdapat dalam Undang-Undang tersebut hanya merupakan peraturan yang tidak ada artinya. Hal ini terlihat masih banyaknya perkawinan di bawah tangan (sirri) yang di lakukan oleh masyarakat (Supriyadi, 2004:36). Perkawinan Sirri ini seolah olah telah mendapat justifikasi masyarakat. Akibatnya banyak perkawinan di bawah tangan tanpa mendapat sanksi sosial oleh masyarakat.

Pengertian perkawinan sirri selalu dikaitkan undangundang perkawinan yaitu undang-undang nomor 1 tahun 
1974, karena istilah perkawinan Sirri muncul sejak dikeluarkannya undang-undang tersebut. Perkawinan Sirri adalah perkawinan yang dilakukan berdasarkan aturan agama atau adat istiadat dan tidak dicatatkan di kantor KUA bagi yang beragama Islam, Kantor Catatan Sipil bagi nonIslam. Ada pendapat yang menyamakan bahwa perkawinan sirri merupakan bagian dari perkawinan dibawah tangan (Hilman, 1984:56). Perkawinan sirri berasal dari bahasa Arab yaitu sirrun yang berarti apa-apa yang dirahasiakan atau apa-apa yang di yang disembunyikan dalam dirinya atau dalam jiwanya, kemudian masuk ke dalam perbendaharaan Bahasa Indonesia yang oleh W.J.S. Poerwadarminta menyebutkan dengan kata-kata sir yang berarti ghaib atau rahasia atau sembunyi. Pengertian istilah kawin sirri dalam bahasa sehari-hari adalah perkawinan yang tanpa dicatatkan pada pegawai pencatat nikah, perkawinan ini dilakukan di depan modin atau kyai dengan dua orang saksi atau dapat diartikan perkawinan tanpa ikatan hukum formil yang berlaku. Dalam kaitanya dengan perkawinan di bawah tangan Prof. Dr. Dadang Hawari (Psikiater \& Ulama) berpendapat bahwa "Telah terjadi upaya mengakali pernikahan dari sebuah prosesi agung menjadi sekedar ajang untuk memuaskan hawa nafsu manusia", ia menilai pernikahan di bawah tangan saat ini banyak dilakukan sebagai upaya legalisasi perselingkuhan atau menikah lagi untuk yang kedua kali atau lebih, sehingga menurutnya pernikahan ini tidak sah.

Berbagai pendapat tentang perkawinan sirri tentu berimplikasi terhadap ketidakpastian tentang status perkawinannya. Dengan demikian dirasa penting untuk dibahas perkawinan Sirri dalam perspektif hukum sehingga diharapkan akan memberikan pencerahan bagi masyarakat.

\section{B. Faktor Faktor Yang Mempengaruhi Perkawinan Sirri}

Perkawinan menurut hukum Islam, yang dalam agama Islam disebut nikah adalah melakukan akad nikah atau perjanjian untuk mengikatkan diri antara seorang lakilaki dan seorang perempuan untuk menghalalkan hubungan kelamin antara kedua belah pihak, dengan dasar suka rela dan keridhoan Allah, kedua belah pihak untuk mewujudkan 
suatu kebahagiaan hidup berkeluarga yang diliputi kasih sayang dan ketentraman denga cara-cara yang diridhoi Allah.(Sumiyati,1997: 8). Tentu dalam perkawinan tersebut juga harus sesuai dengan syarat dan rukun perkawinan. Bertolak dari syarat dan rukumn perkawinan ini sering kali masyarakat melakukan perkawinan tanpa harus dicatatkan atau sering disebut dengan perkawinan sirri.

Seseorang melakukan perkawinan sirri mempunyai latar belakang yang berbeda-beda antara yang satu dengan yang lainya, hal ini tentu disesuaikan dengan kondisi psikologis dan lingkungan atau aspek lain. Ada beberapa pendapat mengapa di Indonesia masih banyak terjadi perkawinan Sirri. Menurut Rohim Kasan Hardjo (Rohim, 86:V), latar belakang perkawinan di bawah tangan/sirri adalah sebagai berikut;

1. Sebagai upaya pencegahan perbuatan negatif diluar nikah, hal ini dapat terjadi bila calon mempelai lakilaki dan wanita sudah demikian intimnya, dikhawatirkan adanya hal-hal yang tidak diinginkan;

2. Untuk menghindari pandangan negatif dari masyarakat;

3. Karena belum adanya sarana keuangan yang dibutuhkan dalam penyelenggaraan perkawinan resmi, baik dari segi administrasi maupun dari segi upacara;

4. Adanya itikat baik (kwade trouw) dengan jalan kawin di bawah tangan, dapat juga dimaksudkan agar seseorang dapat leluasa dari tanggung jawab yang harus dipikul dari seorang suami, bila hal ini terjadi pihak istrilah yang akan menderita, sebab tidak dimilikinya akte perkawinan atau akte nikah.

Disamping latar belakang tersebut diatas ada juga yang melangsungkan perkawinan sirri agar pensiunan janda masih dapat diterima yaitu yang dilakukan oleh janda pegawai negeri, dapat juga disebabkan karena faktor umur calon mempelai laki-laki dan calon mempelai wanita yang masih terlalu muda sehinga bila akan melangsungkan perkawinan secara resmi akan ditolak oleh pegawai pencatat nikah, karena umurnya yang belum cukup untuk melakukan perkawinan (Capita, 1992: 14). 
Secara umum mereka yang melakukan perkawinan sirri mempunyai alasan yang berbeda antara yang satu dengan yang lain, alasan-alasan itu dapat diuraikan sebagai berikut (Supriyadi, 2004: 9) ;

1. Karena ketaatan kepada orang tua, seorang anak akan patuh terhadap keinginan orang tuanya untuk dijodohkan dengan lelaki atau wanita, yang menjadi pilihan orang tuaanya yang bertujuan untuk mendekati tali persaudaraan, sedangkan anak tersebut masih dibawah umur untuk melangsungkan perkawinan;

2. Adanya faktor ekonomi, faktor ini sangat berpengaruh terhadap pelaksanaan perkawinan baik untuk biaya administrasi maupun untuk biaya upacara perkawinan karena belum adanya sarana keuangan, sehingga jalan yang harus ditempuh adalah perkawinan sirri untuk meringannkan biaya.

3. Adanya upaya agar pensiunan dari janda pegawai negeri tersebut untuk tetap menerima pensiunan dari mantan suaminya, ketika ia akan melakukan perkawinan di bawah tangan dengan lelaki lain yang ia cintai.

4. Dalam keadaan kehidupan yang sangat miskin, seorang anak dikawinkan sirri dimaksudkan agar putrinya lepas dari tanggung jawabnya, dan anak tersebut ikut suaminya.

Sebenarnya tujuan utama perkawinan sirri dalam suatu masyarakat adalah antara lain untuk mencegah terjadinya perzinahan, mengikat keluarga yang satu dengan yang lain, menghindari pandangan yang tidak baik dari masyarakat sekitar, Agar putra-putrinya tidak terlalu bebas bergaul dengan pihak lain karenanya keduanya telah terikat tali perkawinan menurut agama maupun adat istiadat.

Jika dibandingkan rumusan menurut hukum Islam diatas dengan rumusan yang ada dalam pasal 1 UUP 1/1974 mengenai pengertian perkawinan tidak ada perbedaan yang prinsip, yang mana dalam perspektif hukum Islam termasuk dalam lapangan muamalat yaitu lapangan yang mengatur hubungan antara manusia dengan kehidupan duniawi. Hubungan antara manusia ini dalam garis besarnya dibagi ke dalam tiga kelompok yaitu ; 
a. Hubungan kerumahtangaan dan kekeluargaan;

b. Hubungan perorangan diluar hubungan kekeluargaan dan rumah tangga,

c. Hubungan antar bangsa dan kewarganegaran.(Supriyadi, 2004: 9).

Hukum perkawinan dalam agama Islam mempunyai kedudukan yang sangat penting, karena diatur dan diterangkan secara jelas dan terperinci. Hukum Islam pada dasarnya tidak hanya mengatur tata cara pelaksanaan perkawinan saja, melainkan juga segala persoalan yang erat hubungannya dengan perkawinan, misalnya hak-hak suami istri, pengatutran harta kekeyaan dalam perkawinan atau kekayaan yang mereka selama perkawinan, biaya hidup yang harus ditanggung sesudah putusnnya perkawinan dan lain-lain.(Kompilasi Hukum Islam, 1998/1999).

Adapun arti penting perkawinan bagi kehidupan manusia khususnya bagi orang yang beragama Islam adalah sebagai berikut ;

a. Dengan melakukan perkawinan yang sah dapat terlaksana pergaulan hidup baik secara individual maupun kelompok antara pria dan wanita secara terhormat dan halal, sesuai dengan kedudukan manusia sebagai mahluk yang terhormat diantara mahluk lain yang diciptakan Tuhan.

b. Dengan melaksanakan perkawinan dapat terbentuk suatu rumah tangga dimana kehidupan dalam rumah tangga dapat terlaksanan secara damai dan tentram serta kekal disertai rasa kasih sayang antara suami dan istri.

c. Dengan melaksanakan perkawinan yang sah diharapkan memperoleh keturunan yang sah dalam masyarakat sehingga kelangsungan hidup dalam keluargnya dan keturunannya dapat berlangsung secara jelas dan bersih

d. Dengan terjadinya perkawinan maka timbul sebuah keluarga yang merupakan inti dari hidup bermasyarakat yang teratur dan berada suasana damai.

e. Melaksanakan perkawinan dengan mengikuti ketentuan-ketentuan yang diatur dalam Al Qur'an dan sunah Rosul adalah merupakan salah satu 
ibadah bagi orang yang beragama Islam.(Supriyadi, 2004: 12).

Tujuan perkawinan dalam ajaran Islam secara garis besar adalah untuk memenuhi hajat tabiat kemanusiaan, berhubungan antara laki-laki dan perempuan dalam rangka mewujutkan suatu keluarga yang bahagia sejahtera dengan dasar cinta dankasih sayang, untuk memperolah keturunan yang sah dalam masyarakat dengan mengikuti ketentuan yang telah diatur dalam syari'ah Islam.

\section{Perkawinan Menurut Undang Undang Nomor 1 tahun 1974}

Undang-Undang Perkawinan dalam pasal 1 merumuskan sebagai berikut: "Perkawinan adalah ikatan lahir bathin antara seorang pria dengan seorang wanita sebagai suami istri dengan tujuan membentuk keluarga (rumah tangga) bahagia dan kekal berdasarkan Ketuhanan Yang Maha Esa".

Dari definisi ini dapat diperinci menjadi ;

a. Perkawinan adalah ikatan lahir batin antara seorang pria dengan seorang wanita;

b. Ikatan lahir itu ditunjukkan untuk membentuk keluarga (rumah tangga) yang bahagia kekal dan sejahtera;

c. Dasar lahir batin dan tujuan yang bahagia kekeal itu berdasarkan pada Ketuhanan Yang Maha Esa;

Sungguh sangat ideal sekali tujuan perkawinan yang di inginkan oleh Undang- Undang perkawinan, tidak hanya dilihat dari segi perjanjian lahiriah, tetapi satu ikatan kebatinan antara suami istri yang ditujukan untuk membentuk dan membina keluarga yang kekal dan bahagia berdasarkan Ketuhanan Yang Maha Esa. Ikatan lahir adalah ikatan yang dapat dilihat secara lahiriah baik antara suami istri maupun masyarakat sekelilingnya dan ikatan batin diperlukan untuk mencerminkan kerukunan suami istri.

Hukum perkawinan mempunyai kedudukan yang sangat penting, oleh karena itu diatur dan diterangkan secara jelas dan terperinci. Selanjutnya diatur dalam PP Nomor 9 tahun 1975 tentang tata cara pelaksanaan perkawinan. Disamping itu hukum perkawinan juga mengatur segala persoalan yang erat hubungannya dengan 
perkawinan, misalnya hak-hak suami istri, pengaturan harta kekayaan dalam perkawinan atau kekayaan yang mereka selama perkawinan, biaya hidup yang harus ditanggung sesudah putusnnya perkawinan dan lain-lain.

Adapun arti penting perkawinan bagi kehidupan manusia khususnya bagi orang yang beragama adalah sebagai berikut;

a. Dengan melakukan perkawinan yang sah dapat terlaksanapergaulan hidup baik secara individual maupun kelompok antara pria dan wanita secara terhormat dan halal, sesuai dengan kedudukan manusia sebagai mahluk yang terhormat diantara mahluk lain yang diciptakan Tuhan;

b. Dengan melaksanakan perkawinan dapat terbentuk suatu rumah tangga dimana kehidupan dalam rumah tangga dapat terlaksanan secara damai dan tentram serta kekal disertai rasa kasih sayang antara suami dan istri;

c. Dengan melaksanakan perkawinan yang sah diharapkan memperoleh keturunan yang sah dalam masyarakat sehingga kelangsungan hidup dalam keluargnya dan keturunannya dapat berlangsung secara jelas dan bersih;

d.Dengan terjadinya perkawinan maka timbul sebuah keluarga yang merupakan inti dari hidup bermasyarakat yang teratur dan berada suasana damai.

Sahnya perkawinan diatur dalam Pasal 2 UndangUndang Nomor 1 tahun 1974 yang menyatakan ;

(1) Perkawinan adalah sah, apabila dilakukan menurut hukum masing masing agamanya dan kepercayaannya itu;

(2) Tiap tiap perkawinan dicatat menurut peraturan perundang-undangan yang berlaku.

Terhadap Pasal 2 tersebut terdapat dua pandangan yang berbeda: Pendapat pertama, menyatakan bahwa perkawinan itu sudah sah apabila dilakukan menurut agama dan kepercayaannya tanpa perlu dicatat oleh pejabat yang berwenang, menurutnya pencatatan hanya merupakan pencatatan peristiwa hukum biasa seperti pencatatan kematian, kelahiran dan lain lain. Perkawinan merupakan 
hak privasi seseorang dan tidak perlu dilakukan pencatatan. Pencatatan oleh pejabat yang berwenang bukan merupakan syarat sahnya perkawinan tetapi merupakan tindakan administrasi saja. Pendapat kedua, Pasal 2 ayat (1) dan ayat (2) tersebut merupakan satu kesatuan yang tidak dapat dipisahkan, sehingga apabila salah satu unsur pasal tersebut tidak dipenuhi maka perkawinannya tidah sah menurut hukum (Wibowo, 1982: 11).

Terhadap dua pandangan di atas penulis sependapat dengan pendapat yang kedua, adapun dasar argumentasi hukumnya adalah sebagai berikut;

1. Pasal 2 (2) telah dirumuskan secara organik oleh pasal 2 (1), Pasal 3-9 dalam PP 9/1975 tentang tata cara pelaksanaan UU perkawinan;

2. KHI Inpres No. 1/1991 dan Kemenag No.154/1991 pasal 5, 6 dan 7 (1) memperkuat bahwa pencatatan menjadi syarat sahnya akad nikah;

3. Yurisprodensi MA RI No. 1948/K/Pid/1991; pertimbangan hukum: yang dimaksud perkawinan menurut UU No 1/1974 adalah perkawinan yang dilangsungkan di hadapan pejabat KUA;

4. SE BAKN No. 48/SE/1990 tentang petunjuk pelaksanaan PP No. 45/1990 butir IX: istri PNS yang dinikahi sah yaitu sesuai dengan pasal 2 (1) dan Pasal 2 (2) UU perkawinan.

Adapun syarat-syarat perkawinan diatur dalam Pasal 6 s.d Pasal 12 UU 1/1974, Pasal 6 menyatakan sebagai berikut adalah sebagai berikut ;

1. Perkawinan harus didasar atas persetujuan kedua calon mempelai;

2. Untuk melangsungkan perkawinan seorang yang belum mencapai umur 21 tahun harus mendapat izin kedua orang tua;

3. Dalam hal salah satu orang tua sudah meninggal dunia atau dalam keadaan tidak mampu menyatakan kehendaknya maka izin dimaksud ayat (2) pasal ini cukup diperoleh dari orang tua yang masih hidup atau dari orang tua yang mau menyatakan kehendaknya;

4. Dalam hal kedua orang tua sudah meninggal dunia atau dalam keadan tidak mampu menyatakan 
kehendaknya maka izin diperoleh dari wali,orang yang memelihara atau keluarga yang mempunyai hubungan darah dalam garis keturunan lurus keatas selama mereka masih hidup dalam keadaan dapat menyatakan kehendaknya;

5. Dalam hal ada perbedaan pendapat antara orang orang dalam ayat (2), (3) dan (4) pasal ini, atau salah seorang atau lebih diantara mereka tidak menyatakan pendapatnya maka pengadilan dalam daerah hukum tempat tingal orang yang akan melangsungkan perkawinan atas permintaan orang tersebut dapat memberikan izin setelah lebih dahulu mendengar orang-orang tersebut dalam ayat (2), (3) dan (4) pasal ini;

6. Ketentuan tersebut ayat (1) sampai dengan ayat (5) pasal ini berlaku sepanjang hukum masing-masing agamanya dan kepercayannya itu dari yang bersangkutan tidak menentukann lain.

Selanjutnya Pasal 7 UUP No. 1 tahun 1974 menyatakan ;

a. Perkawinan hanya diizinkan jika pihak pria sudah mencapai umur 19 (sembilan belas) tahun dan pihak wanita sudah mencapai umur 16 (enam belas) tahun;

b. Dalam menyimpang dalam ayat (1) pasal ini dapat meminta dispensasi pengadilan atau pejabat lain yang ditunjuk oleh kedua orang tua pihak pria maupun pihak wanita;

c. Ketentuan ketentuan mengenai keadaan salah seorang atau kedua orang tua tersebut dalam pasal 6 ayat (3) dan (4) Undang-undang ini, berlaku juga dalam hal permintaan dispensasi tersebut ayat (2) pasal ini dengan tidak mengurangi yang dimaksud dalam pasal 6.

Sedangkan Pasal 8 s.d Pasal 12 mengatur tentang larangan perkawinan karena hubungan darah atau berhubungan dengan salah satu pihak terikat oleh tali perkawinan lain.

Adapun tata caranya diatur dalam Peraturan Pemerintah Nomor 9 tahun 1975 tentang undang-undang nomor 1 tahun 1974 tentang perkawinan. 
Berdasarkan argumentasi diatas menurut hemat penulis maka perkawinan Sirri merupakan perkawinan yang tidak sah dalam perspektif Undang-Undang Perkawinan Nomor 1 tahun 1974. Perkawinan sirri tidak memiliki akta otentik, sehingga seseorang yang melakukan perkawinan di bawah tangan akan kesulitan membuktikan tentang terjadinya perkawinannya

\section{Implikasi Perkawinan Sirri}

1. Kedudukan suami istri

Sebagaimana diuraikan diatas bahwa Perkawinan adalah sah, apabila dilakukan menurut hukum masing-masing agama dan kepercayannya dan tiap-tiap perkawinan dicatat menurut peraturan perundangan yang berlaku (Pasal 2 UUP 1 tahun 1974). Perkawinan sirri tidak memenuhi rumusan perundang-undangan ini maka perkawinannya merupakan perkawinan yang tidak sah, sehingga hubungan suami istri ini hanya didasarkan pada kepercayaan. Kedudukan suami istri hanya sah menurut hukum agama dan kepercayaanya tetapi dalam hukum negara mereka dianggap belum pernah terjadi perkawinan.

Menurut UUP No. 1 /1974 adanya perkawinan yang dilakukan di bawah tangan merupakan perkawinan yang belum memenuhi ketentuan Pasal 2 ayat (2) undang-undang ini dan tidak diakui oleh Kantor Urusan Agama selaku pejabat yang berwenang melakukan pencatatan. Perkawinan mereka hanya memenuhi syarat-syarat yang telah ditentukan dalam pasal 2 ayat (1) UU No. 1 /1974. Dapat dikatakan bahwa karena perkawinan dibawah tangan keberadaannya tidak diakui oleh negara, baik mengenai sahnya perkawinan maupun segala sesuatu akibat yang ditimbulkan dari perkawinan tersebut.

2. Kedudukan anak/ hubungan orang tua dengan anak

Dalam suatu perkawinan yang kemudian menghasilkan atau terlahir anak. Kedudukan anak dan bagaimana hubungan antara orang tua dengan anaknya akan timbul suatu permasalahan. Oleh 
karena itu pemerintah mengatur permasalahan tersebut agar di kemudian hari tidak timbul permasalahan yang tidak diinginkan sebagaimana diatur dalam Pasal 42 dan 43 UUP No. 1/ 1974 tentang perkawinan.

Anak yang dilahirkanya mempunyai kedudukan tidah sah menurut hukum formil, sebab dalam pasal 42 UUP No. 1/1974 yang dimaksud anak sah adalah anak yang dilahirkan dalam atau sebagai akibat perkawinan sah, sedang dalam pasal 43 UUP No. 1/1974 disebutkan bahwa anak yang dilahirkan diluar perkawinan hanya mempunyai hubungan keperdataan dengan ibunya atau keluarga ibunya.

Berdasarkan pasal 43 ayat 1 UUP No. 1/1974 ini maka anak yang lahir dari perkawinan sirri tidak mempunyai hubungan secara perdata dengan ayahnya atau keluarga ayahnya, meskipun dalam kenyataannya menurut hukum adat setempat anak tersebut tetap diakui keberadaan oleh ayahnya beserta keluarga ayah. Yang menjadi persoalan adalah ketika pasangan perkawinan dibawah tangan terjadi perceraian atau pasangan tersebut meninggal dunia. Persoalan yang muncul adalah kepada siapa harta warisan peninggalan pewaris tersebut tersebut harus dibagi (dalam kaitanya dengan UUP No. 1/ 1974 ).

Tolok ukur dari anak yang lahir diluar perkawinan tentu ukurannya sesuai dengan rumusan mengenai perkawinan itu sendiri menurut UU No. 1 Tahun 1974 , dimana menurut ketentuan UU No 1 tahun 1974 perkawinan itu sah apabila dilakukan menurut hukum masing-masing agama dan kepercayaannya itu dan tiap-tiap perkawinan dicatat menurut peraturan perundang-undangan yang berlaku. Dengan demikian sekalipun suatu perkawinan itu sah tetapi bila tidak dicatatkan, maka anak yang lahir dari perkawinan yang sah yang tidak dicatatkan itulah yang ditergolong anak yang lahir diluar perkawinan. Anak yang lahir diluar perkawinan itu lazimnya hasil suatu perkawinan di 
bawah tangan, bahkan kemudian popular juga disebut kawin siri. Tidak sedikit persoalan yang muncul dalam masyarakat yang bersumber dari perkawinan dibawah tangan, termasuk pengakuan terhadap seorang anak yang lahir diluar perkawinan. Meskipun disisi lain ada yang menerima keadaan serupa itu apa adanya, walaupun dari segi formalitas hukum, anak-anak yang lahir diluar perkawinan mengalami kesulitan dalam memahami statusnya. Pro-kontra terhadap keberadaan atau status anak yang lahir diluar perkawinan sudah berlansung sejak lama dan sejumlah ahli telah memberikan pandangannya, dengan hilangnya hubungan keperdataan antara anak yang lahir diluar perkawinan dengan orang tua laki-lakinya. Namun berdasarkan putussan Mahkamah Konstitusi Nomor 46/PUU-VIII/ 2010 tanggal 12 Februari 2012, terjadi perubahan yang mendasar. (http:/ / boyyendratamin.blogspot.com/2012/03/ked udukan-anak-diluar perkawinanan.html).

Pasal 43 ayat 1 UU Perkawinan dikabulkan karena hubungan anak dengan seorang laki-laki sebagai bapak tidak semata-mata karena adanya ikatan perkawinan, akan tetapi dapat juga didasarkan pada pembuktian adanya hubungan darah antara anak dengan laki-laki tersebut sebagai bapak. Dengan demikian, terlepas dari soal prosedur/administrasi perkawinannya, anak yang dilahirkan harus mendapat perlindungan hukum. Jika tidak demikian, maka yang dirugikan adalah anak yang dilahirkan di luar perkawinan, padahal anak tersebut tidak berdosa karena kelahirannya di luar kehendaknya.

Komisi perlindungan anak Indonesia (KPAI) mengungkapkan hampir 50 juta anak di Indonesia tidak memiliki akta kelahiran karena berbagai sebab antara lain karena pernikahan tidak sah atau tercatat di atau kawin sirri, angka ini hampir separuh dari total jumlah anak dibawah 5 tahun yang ada di Indonesia. KPAI sangat mengapresiasi putusan MK beberapa waktu lalu yang mengabulkan 
permohonan uji materiil atas pasal anak diluar pernikahan sah dalam UU perkawinan. Menurut ketua Komnas perlindungan Anak Aris Merdeka Sirait, perubahan pada Undang-undang Perkawinan oleh Mahkamah Konstitusi ini akan menjadi landasan hukum yang sah dalam memajukan upaya advokasi bagi anak-anak diluar pernikahan yang sah untuk memperoleh hak keperdataannya. "Jadi putusan MK kemarin memberikan hak keperdataan yang selama ini tidak diakui negara. Makanya akta lahirnya itu tidak mencantumkan nama ayah. Dan tentu ini akan berimplikasi tidak mendapatkan "hak waris" dan tidak bisa mencantumkan siapa bapaknya, hal ini sangat merugikan anaknya. Didalam konvensi PBB juga pengakuan keperdataan dalam bentuk identitas nama dan kewarganegaraan itu harus diberikan oleh negara, tidak harus bergantung pada sah tidaknya perkawinan. Tetapi juga sebagai hak konstitusi, hak keperdataan, itu adalah hak yang sangat mendasar dan konstitusional".

(http://www.jimlyschool.com/read/analisis/256/p utusan-mahkamah-konstitusi-tentang-status-anakluar-kawin/).

Pasal 42 UUP 1/1974 yang mengatur mengenai sah tidaknya anak, maka harta warisan selama perkawinan di bawah tangan berlangsung, yang berupa harta bawaan ayah apabila dikaitkan dengan UUP No.1 1974, harta tersebut bukan jatuh pada anak melainkan jatuh pada pihak keluarga ayah, sebab anak yang dilahirkan dalam perkawinan dibawah tangan tersebut hanya mempunyai hubungan keperdataan dengan ibunya atau keluarga ibunya, sedang ayahnya tidak memmpunyai hubungan apa-apa dengan anak tersebut.

3. Harta Kekayaan

Undang-undang perkawinan hanya mengatur tentang harta dalam perkawinan sah, sedang harta untuk perkawinan sirri tidak diatur dalam undangundang nomor 1 tahun 1974. Harta yang diperoleh 
dalam perkawinan diatur dalam pasal 35 ayat 1 UUP No. 1/ 1974, yang menyatakan bahwa harta benda yang diperoleh selama perkawinan menjadi harta bersama. Jika masing-masing suami istri membawa harta ke dalam perkawinannnya atau selama perkawinan itu masing-masing memperoleh hadiah atau warisan, maka harta tersebut tetap menjadi milik dan dikuasai masing-masing pihak, kecuali para pihak menentukan lain sehingga menjadi harta bersama.. Tentang harta bersama baik suami maupun istri dapat mempergunakannya dengan persetujuan salah satu pihak, sedang mengenai harta bawaan, masing-masing mempunyai hak sepenuhnya atas harta tersebut. Apabila perkawinan tersebut putus maka tentang harta bersama diatur menurut hukumnya masing-masing artinya hukum agama, hukum adat ataupun akan tunduk terhadap yang diatur dalam Kitab Undang-undang Hukum Perdata. Sebab mengenai pewarisan dalam UU 1 /1974 belum diatur secara jelas mengenai pembagian harta waris kepada anak. Karena belum diatur dalam UUP No. 1/ 1974 maupun PP 9 / 1975 maka berdasarkan pasal 66 UU 1/ 1974 di sebutkan " Untuk perkawinan dan segala sesuatu yang berhubungan dengan perkawinan berdasarkan atas undang-undang ini, maka dengan berlakunya undang-undang ini ketentuan-ketentuan yang diatur dalam Kitab Undang-undang Hukum Perdata (bugelijk wetboek ), Ordonansi perkawinan Indonesia Kristen ( Huwelijk Ordonannatie Christen Indonesiers S. 1933 No 74 ), Peraturan perkawinan Campuran (Regeling Opde gemengde Huwelijken S. 1898 No 158 ), dan peraturan lain yang mengatur tentang perkawinan sejauh telah diatur dalam undang-undang ini, dinyatakan tidak berlaku".

Berdasarkan pasal 66 UU I / 1974, maka dapat dikatakan bahwa peraturan tentang perkawinan berlaku secara nasional yang dijadikan pedoman dasar bagi pelaksanaan perkawinan untuk seluruh bangsa Indonesia. Tetapi dalam hal pembagian warisan terhadap anak dilakukan 
menurut hukumnya masing-masing dalam artian masyarakat dapat menggunakan hukum waris adat, hukum waris agama, atau tunduk kepada hukum waris yang diatur dalam Kitab Undang-undang Hukum Perdata. Bagi mereka yang melangsungkan perkawinan menurut hukum adat, maka maka pembagian warisan dilakukan menurut hukum adat, apabila perkawinan dilakukan menurut hukum agama, maka pembagian warisan dilakukan menurut hukum agama yang diyakini demikian juga terhadap mereka yang tunduk dalam Kitab Undang-undang Hukum Perdata.

\section{E. Kesimpulan}

Istilah perkawinan Sirri muncul sejak dikeluarkannya undang-undang tersebut. Perkawinan Sirri merupakan perkawinan yang dilakukan berdasarkan aturan agama atau adat istiadat dan tidak dicatatkan dikantor Kantor Urusan Agama bagi yang beragama Islam, Kantor Catatan Sipil bagi non-Islam. Perkawinan ini hanya sah menurut hukum agama atau kepercayaan tetapi perkawinan ini tidak sah menurut hukum formil negara, karena perkawinan di bawah tangan tidak diakui oleh pemerintah. Perkawinan dibawah tangan berimplikasi terhadap ketidakjelasan status hubungan suami isteri, kedudukan anak yang hanya mempunyai hubungan keperdataan dengan ibunya dan kekuarga ibunya dan ketidakjelasan tentang harta kekayaan yang diperoleh selama perkawinan sebagai tidak bisa dibuktikannya status perkawinannya. 
Perkawinan Sirri dalam Perspektif Hukum di Indonesia...

\section{DAFTAR PUSTAKA}

Capita Airlangga Umardi P, Makalah seminar regional Fak hukum UMK, 1992, Tidak dipublikasikan

Hilman Hadi Kusuma, Pokok-pokok Hukum Adat, Pradnya Paramita, 1984.

1991.

M.A Rohim Kasan Hardjo, Sebab-sebab perkawinan sirri, Surabaya post, Kamis, 16, Januari, 1986

Supriyadi, Pelaksanaan kewarisan terhadap anak sebagai akibat perkawinan sirri di Kecamatan Pancur Kabupaten Rembang, Hasil penelitian, 2004

Wibowo Reksopradoto, Hukum Perkawinan Nasional, Seksi Hukum perdata Fakultas Hukum UNDIP, Semarang, 1982

Kompilasi Hukum Islam di Indonesia, Direktorat Pembinaan Badan Pertadilan Agama, Departemen Agama RI, Tahun 1998/1999 